\title{
The Implications of Board Independence and Foreign Ownership on Audit Quality of Manufacturing companies in Nigeria
}

\author{
Solomon Oriakhi a 1 iD, Emma I. Okoye b ${ }^{\text {iD }}$, Segun Idowu Adeniyi ${ }^{\text {b }}$ iD \\ ${ }^{a}$ Edo State Polytehnic Usen, Edo State, Nigeria \\ ${ }^{b}$ Nnandi Azikwe University, Awka, Nigeria
}

\begin{abstract}
APA Citation:
Oriakhi, S., Okoye, E. I., \& Adeyini, S. I. (2021). The implications of board independence and foreign ownership on audit quality of manufacturing companies in Nigeria. TIJAB (The International Journal of Applied Business), 5(2), 111-124.

Submission Date: 05/07/2021

Acceptance Date: 02/11/2021
\end{abstract}

\begin{abstract}
This study investigated the implications of board independence and foreign ownership on audit quality of Nigeria manufacturing companies. The specific objectives of the study are to examine the effects of board independence as well as foreign ownership on the quality of audit of Nigeria quoted manufacturing companies. The study employed secondary data to carefully collect a total of fifty eight (58) Nigeria quoted manufacturing companies for the period of 2010 to 2018. The binary model of regression (logit, probit as well as gombit) was properly used to test the hypotheses. The outcome reveals that board independence had a positive as well as insignificant influence on audit quality while foreign ownership had a positive and a significant influence on audit quality. The study then recommends that composition of the board should be such that its function is not undermined and one of such ways is to have an appropriate mixture with non-executive directors. Also having foreign ownership could enhance audit quality given the different corporate cultures they may possess.
\end{abstract}

Keywords: audit quality; board independence; foreign ownership; manufacturing firms; Nigeria.

This is an open access article under the CC BY-NC-SA license.

\section{Introduction}

Corporate governance has been understood as an important tool in assessing the company's health, especially under financial distress conditions. The main factors blamed for company failure is perhaps the weakness of corporate governance (Nengzih, 2017). Corporate governance is the company's management through the board of directors that centers on complete integrity, transparency and management accountability. The Nigerian Code of Corporate Governance 2018, made it mandatory for all listed firms in Nigeria to audit their financial statements at every financial year end. This is because audit quality gives credibility and integrity to the financial statements of companies and those that make

\footnotetext{
${ }^{1}$ Corresponding author.

E-mail address: solomon.oriakhi@yahoo.com
} 
user of the financial statements rely on the audited reports of the investing companies. Therefore, auditors are to give their opinion on the audited financial statements.

Similarly, the Nigeria Corporate governance code 2018 made it mandatory for quoted firms to have independent board. "A board comprising a reasonable proportion of inside and outside directors is more likely to be independent of management than one dominated by insider directors, and therefore more likely to protect the interest of other stakeholders in the firm" (John \& Senbet, 1998, cited in Ilaboya \& Iyafekhe, 2014, p. 174). However, some quoted manufacturing firms in Nigeria do not yield to the content of the code of corporate governance in the composition of their board of directors and this may likely have effect on the quality of audit firms. In the same vein, Oxelheim and Randov (2003) conducted study on Swedish companies and discovered that foreign owners who can secure at least one foreign representative on the director's board is a signal of greater commitment towards corporate governance and transparency, and this signal in turn result in better reputation and higher firm value in the financial market. Despite the significant nature of foreign ownership and board independence in relation to audit quality, very few studies have examined board independence and foreign ownership as the variables of corporate governance having effect on the quality of audit (Kakler, Kangarlovei \& Motavassel 2012; Kee, Hock \& Kueng 2017). Also, inadequate research/literature on corporate governance variables, i.e., foreign ownership and board independence on audit quality of Nigeria quoted manufacturing companies has also been identified by this study. Therefor the study addresses the identified gap.

Therefore, in a bid to investigate the implications of board independence as well as foreign ownership on the quality of audit of the Nigeria quoted manufacturing companies is the reason for this study. This study is undertaken to add to the literature of corporate governance as it relates to audit quality using data from Nigeria companies. To this end, the specific objectives are stated, followed by the review of literature and development of hypotheses, methodology, data analysis, hypotheses testing, discussion of findings, conclusion and recommendation.

Objectives of the study

1. To examine the nexus between board independence and audit quality of Nigeria quoted manufacturing companies.

2. To investigate the nexus between foreign ownership and audit quality of Nigeria quoted manufacturing companies.

\section{Literature Review}

\subsection{The Concept of Audit Quality}

A considerable number of literatures dealing in particular with audit quality have been developed. A good number of the research literature examining the quality of audit relies on the economic view represent in various definitions. "Audit quality is the identification and reporting of substantial misrepresentation of facts in financial statements by an auditor (De Angelo, 1981), which represents the competence of the auditor" (as cited in Wakil, Alifiah \& Teru, 2020, P. 839). Thus, the quality of audit is related to the perceptions of two key factors of audit quality: Independence and competence. Dwekat, Mardawi and Abdeljawad (2018) argued that the assessment of the quality of audit is costly as a result of the inadequate ability of the consumers to detect the procedures of audit that is use in audit engagement as well as the inadequate information about incentives surrounded by the auditor-client contract and they suggested the use of the size of the auditor as a substitute for the quality of auditor. According to them, big audit firms can be of better quality when compared with other auditors as a result of their economic trust which they have on any single client. The aim of the function of external audit is recognized by the American Institute of Certified Public Accountants as well as the International 
Auditing and Assurance Standards Board as getting hold of reasonable assurance as regards to whether financial statements that is been reported communicate results to interested parties and are free of material misstatements (Rittenberg, Johnstone \& Gramling, 2010).

\subsection{Board Independence and Audit Quality}

The Independence board is a member of the board of officials that has no relationship with the company. It is seen as the non-executive director on the company's board. The significance of board independence has been known with the codes of corporate governance to give a due reflection to the need of having a significant percentage of them on the board of quoted companies in Nigeria. It is generally believed that outside directors are more effective when monitoring management and enhancing financial reporting quality. The determinants of audit quality in business environment of Nigeria were investigated by Enofe et al. (2013) and the study revealed a relationship that is positive between the board independence and quality of audit. In the same vein, Stewart and mason (2006) also revealed the proportion of independent directors to have a positive and significant impact on the quality of audit.

To formally test the nexus between board independence and audit quality of Nigeria quoted manufacturing companies, we develop the following hypothesis:

Board independence does not have any significant influence with the audit quality of Nigeria quoted manufacturing companies.

\subsection{Foreign Ownership and Audit Quality}

Several studies have explored the variables of corporate governance on audit quality in developed as well as developing countries. Foreign investment plays a crucial role in capital formation and economic development particularly in developing and emerging economics (Ling, Chiek \& Seong, 2016). According to Gillan and Stark (2003) foreign investors encourage companies to adopt better governance practices. Most studies of foreign ownership structure have over looked the possibility that executive directors who actually control the daily operations and strategic decision makings might have maximized personal wealth at shareholders expense (Tambun et al., 2017). Peel \& Makepeace (2012) study on Swedish companies discovered that foreign owners who can secure at least one foreign representative on the director's board is a signal of greater commitment towards corporate governance and transparency, and this signal in turn result in better reputation and higher firm value in the financial market. Uwuigbe et al. (2018) investigated corporate governance and financial statements quality of Nigeria listed banks and found a relationship that is significant between foreign ownership and the quality of audit. Akinwunmi, Adeyemi, Alao and Ajayi-owoeye (2020) also conducted study on foreign ownership structure as a tool to monitor the quality of audit in Nigeria. The study revealed a relationship that is significant between foreign ownership and the quality of audit.

To formally test the nexus between foreign ownership and audit quality of Nigeria quoted manufacturing companies, we develop the following hypothesis:

Foreign ownership does not have any significant influence with the audit quality of Nigeria quoted manufacturing companies.

\section{Method}

Panel data design was adopted for this study. Panel data design is the combination of cross sectional and that of time series design properties. Fifty - eight (58) quoted manufacturing firms in Nigeria as at December, 2018 formed the population of the study. The entire population of this study is also selected 
as sampling size of the study. This is because the financial data of quoted manufacturing firms in the Nigeria Stock Exchange are accessible. Secondary data were collected from the manufacturing firm's financial statements that are audited between the years 2010-2018. Binary regression analysis was adopted for the analysis of data collected for the study with the aid of binary model (Logit, Probit and Gompit).

The model of Akhalumeh, Agweda and Ogunkuade (2017) was adopted in this study and the model is stated below:

$$
\mathrm{AUDQ}=\beta 0+\beta 1 \mathrm{FSZ}+\beta 2 \mathrm{BDIN}+\beta 3 \mathrm{BDSZ}+\beta 4 \mathrm{FINL}+\beta 5 \mathrm{FPR}+\mathrm{e}
$$

Where,

$$
\begin{aligned}
& \text { AUDQ = Audit quality } \\
& \text { FSZ = Firm size } \\
& \text { BDIN = Board independence } \\
& \text { BDSZ = Board size } \\
& \text { FINL = Financial leverage } \\
& \text { FPR = Firm profitability }
\end{aligned}
$$

Premise on the above model, the current study functional form develops its model as follows;

$$
A Q=f(B I N D, F O W N E R)
$$

Where,

$$
\mathrm{AQ}=\text { Audit Quality }
$$

BIND $=$ Board Independence

FOWNER = Foreign Ownership

In order for variable omission bias to be account for, audit firm size will be used as control variable in the study. When control variable (firm size) is integrated into the above model, the model functional form will appear as follows:

$A Q=f(B I N D$, FOWNER, AFSIZE $)$

Where,

\section{AFSIZE $=$ Audit Firm Size}

The above equation can therefore be restated in the form of a binary regression as:

$\operatorname{Logit}(\mathrm{AQ})=\ln (\mathrm{P}(\mathrm{AQ}) /(1-\mathrm{P}(\mathrm{AQ})))=\gamma_{-} 0+\gamma_{-} 1$ BIND $+\gamma_{-} 2$ FOWNER $+\llbracket \gamma \rrbracket \_3$ AFSIZE $+\mu$ (iii)

$\operatorname{Probit}(\mathrm{AQ})=\ln (\mathrm{P}(\mathrm{AQ}) /(1-\mathrm{P}(\mathrm{AQ})))=\gamma_{-} 0+\gamma_{-} 1 \mathrm{BIND}+\gamma_{-} 2$ FOWNER $+\llbracket \gamma \rrbracket \_3$ AFSIZE $+\mu$ (iv)

$\operatorname{Gompit}(\mathrm{AQ})=\ln \ln (\mathrm{P}(\mathrm{AQ}) /(1-\mathrm{P}(\mathrm{AQ})))=\gamma_{-} 0+\gamma_{-} 1 \mathrm{BIND}+\gamma_{-} 2$ FOWNER $+\llbracket \gamma \rrbracket \_3$ AFSIZE $+\mu$ (v)

$\gamma 0=$ Constant 
$\gamma 1-3=$ The variables unknown coefficients

$\mu=$ error term

Decision

The decision rule is to accept the alternate hypothesis and reject the null hypothesis where the $\mathrm{P}$ value $<0.05$ or to reject the alternate hypothesis (HA) and accept the null hypothesis (H0) where the $\mathrm{P}$ value $\geq 0.05$.

Table 1. Operationalisation of variables

\begin{tabular}{|c|c|c|c|c|}
\hline Variables & Notation & Measurement & Nature & Source \\
\hline Audit Quality & $\mathrm{AQ}$ & $\begin{array}{l}\text { Audit quality is dichotomy in nature } \\
\text { and audit firm size (Big } 4 \text { or non-Big } \\
\text { 4) is employed to proxy audit quality. }\end{array}$ & Dependent & $\begin{array}{l}\text { Enofe et al. } \\
(2014)\end{array}$ \\
\hline $\begin{array}{l}\text { Board } \\
\text { Independence }\end{array}$ & BIND & $\begin{array}{l}\text { Ratio of non-executive directors to } \\
\text { the company's board size. }\end{array}$ & Independent & $\begin{array}{l}\text { Okaro et al. } \\
(2015)\end{array}$ \\
\hline $\begin{array}{l}\text { Foreign } \\
\text { Ownership }\end{array}$ & FOWNER & $\begin{array}{l}\text { Firms adopt better governance } \\
\text { practices. }\end{array}$ & Independent & $\begin{array}{l}\text { Ling et al. } \\
(2016)\end{array}$ \\
\hline Audit Firm Size & AFSIZE & $\begin{array}{l}\text { Natural logarithm of total revenues of } \\
\text { audit firms. }\end{array}$ & Control & $\begin{array}{l}\text { Chen, Hsu, } \\
\text { Huang and } \\
\text { Yang (2013). }\end{array}$ \\
\hline
\end{tabular}

Source: Researcher, 2020.

\section{Results}

Table 2. Descriptive statistics

\begin{tabular}{|c|c|c|c|c|}
\hline \multicolumn{5}{|c|}{ FULL SAMPLE } \\
\hline & AQ & BIND & FOWNER & AFSIZE \\
\hline Mean & 0.521 & 0.638 & 22.482 & 299 \\
\hline Maximum & 1.000 & 0.990 & 87.950 & 732 \\
\hline Minimum & 0.000 & 0.000 & 0.000 & 200 \\
\hline Std. Dev. & 0.500 & 9.247 & 28.434 & 648 \\
\hline Jarque-Bera & 84.168 & 661 & 72.865 & 430 \\
\hline Probability & 0.000 & 0.000 & 0.000 & 0.000 \\
\hline Obs. & 505 & 505 & 505 & 505 \\
\hline \multicolumn{5}{|c|}{ CONSUMER GOODS SAMPLE } \\
\hline Mean & 0.705 & 0.636 & 26.278 & 267 \\
\hline Maximum & 1.000 & 6.000 & 74.970 & 367 \\
\hline Minimum & 0.000 & 0.250 & 0.000 & 350 \\
\hline Std. Dev. & 0.457 & 0.436 & 29.528 & 432 \\
\hline Jarque-Bera & 33.565 & 127 & 22.917 & 789 \\
\hline Probability & 0.000 & 0.000 & 0.000 & 0.000 \\
\hline Obs. & 173 & 173 & 173 & 173 \\
\hline \multicolumn{5}{|c|}{ OIL \& GAS AND NAUTRAL RESOURCES SAMPLE } \\
\hline Mean & 0.375 & 0.683 & 20.338 & 241 \\
\hline Maximum & 1.000 & 0.690 & 70.430 & 257 \\
\hline Minimum & 0.000 & 0.000 & 0.000 & 270 \\
\hline Std. Dev. & 0.486 & 16.974 & 27.765 & 756 \\
\hline Jarque-Bera & 24.427 & 118 & 24.144 & 339 \\
\hline Probability & 0.000 & 0.000 & 0.000 & 0.000 \\
\hline Obs. & 144 & 144 & 144 & 144 \\
\hline \multicolumn{5}{|c|}{ HEALTH, CONGLOMERATE AND AGRICULTURE SAMPLE } \\
\hline Mean & 0.486 & 0.617 & 21.066 & 265 \\
\hline Maximum & 1.000 & 0.900 & 87.950 & 732 \\
\hline
\end{tabular}




\begin{tabular}{lcccc}
\hline Minimum & 0.000 & 0.330 & 0.000 & 200 \\
Std. Dev. & 0.501 & 0.123 & 28.322 & 668 \\
Jarque-Bera & 29.833 & 3.246 & 26.927 & 370 \\
Probability & 0.000 & 0.197 & 0.000 & 0.000 \\
Obs. & 179 & 179 & 179 & 179 \\
\hline
\end{tabular}

Source: Compilation of the Researchers (2020).

Where; AQ = Audit Quality; BIND = Board Independence, FOWNER= Foreign Ownership; and AFSIZE= Audit Firm Size.

Table 2 indicates the descriptive statistics result. In the full sample, the descriptive statistics for AQ revealed 1(0.521) approximately mean value and this shows that the big-4 audit firms are used by the sample firms on the average, which shows that industry specialized audit firm audit majority of the sampled firms. The 0.500 standard deviation suggests the extent of the mean value dispersion from distribution. BIND shows 0.638 as the mean value which suggests that about $63.8 \%$ of the sampled firms constitute none-executive directors with 0.990 standard deviation. FOWNER has 22.482 as the mean value and this indicates that the total equity holding by foreign investors in the sampled firms is about $22.48 \%$ with 28.434 standard deviation. On the part of the control variable, AFSIZE has 299 as the mean value and this shows the amount of audit fees paid on the average by the sampled firms is N299 million, with 648 standard deviations. For consumer goods sector, on the part of the sub-samples, AQ revealed 1(0.705) approximately mean value and this shows that the big-4 audit firms are by the consumer goods sector companies on the average, which shows that industry specialized audit firm audit more of the sampled firms with 0.457 standard deviation. BIND shows 0.636 as the mean value and this suggest that about $63.6 \%$ of consumer goods sector companies' board of directors constitute noneexecutive directors with the standard deviation of 0.436. FOWNER shows 26.278 as the mean value and this shows that the total equity holdings by foreign investors is about $26.28 \%$ in the consumer sector firms with 29.528 standard deviation. AFSIZE (control variable) reveals 267 as the mean value and this indicates that the amount of audit fees that is paid by the consumer sector firms on the average is 267 million with 432 standard deviation value. For the sector of oil \& gas and other natural resources, AQ reveals 0.375 as the mean value which shows that the non-big- 4 audit firms are used by the sector firms of oil \& gas and other natural resources on the average and this shows that non-industry specialized audit firm audit more of the sampled firms of the sector of oil \& gas and other natural resources with 0.486 standard deviation. BIND shows 0.683 as the mean value and this suggest that $68.3 \%$ of the sector firms' board of directors for oil \& gas and other natural resources constitute none-executive directors with 0.690 standard deviation. FOWNER shows 20.338 as the mean value and it suggests that the total equity holdings by foreign investors of the sampled firms in the sector of oil \& gas and other natural resources is $20.34 \%$ with 27.765 standard deviation value. AFSIZE (control variable) reveals 241 as the mean value and this shows that the amount of audit fees paid by the sampled firms of the sector of oil $\&$ gas and other natural resources on the average is 4 million with 756 standard deviation value. For the sectors of health, conglomerate and agriculture, AQ reveals 0.486 as the mean value and this shows that the sectors firm for health, conglomerate and agriculture on the average used the non-big- 4 audit firms and this shows that the non-industry specialized audit firm audit more of the sectors firms of health, conglomerate and agricultural with 0.501 as the standard deviation. BIND shows 0.617 as the mean value and this suggests that about $61.7 \%$ sectors firms' board of directors of conglomerate, health and agriculture constitute none-executive directors with 0.123 as the standard deviation value. FOWNER shows 21.066 as the mean value of and this indicates that the total equity holdings by foreign investors in the sectors firms of health, conglomerate and agriculture is about $21.07 \%$ with the standard deviation value of 28.322. On the aspect of the control variable, AFSIZE indicates 265 as the mean 
value and this shows that the amount of audit fees paid by sectors firms of health, conglomerate and agricultural on the average is 265 million with 668 as the standard deviation value.

Table 3. Correlation results

\begin{tabular}{|c|c|c|c|c|}
\hline & $\mathrm{AQ}$ & BIND & FOWNER & AFSIZE \\
\hline \multicolumn{5}{|c|}{ FULL SAMPLE } \\
\hline $\mathrm{AQ}$ & 1 & & & \\
\hline BIND & $\begin{array}{l}0.128^{*} \\
(0.003)\end{array}$ & 1 & & \\
\hline FOWNER & $\begin{array}{l}0.334^{*} \\
(0.000)\end{array}$ & $\begin{array}{l}-0.105^{*} \\
(0.017)\end{array}$ & 1 & \\
\hline AFSIZE & $\begin{array}{l}0.500^{*} \\
(0.000)\end{array}$ & $\begin{array}{l}-0.080 \\
(0.073)\end{array}$ & $\begin{array}{l}0.400^{*} \\
(0.000)\end{array}$ & 1 \\
\hline \multicolumn{5}{|c|}{ CONSUMER GOODS SAMPLE } \\
\hline $\mathrm{AQ}$ & 1 & & & \\
\hline BIND & $\begin{array}{l}-0.091 \\
(0.233)\end{array}$ & 1 & & \\
\hline FOWNER & $\begin{array}{l}0.281^{*} \\
(0.000)\end{array}$ & $\begin{array}{l}-0.069 \\
(0.365)\end{array}$ & 1 & \\
\hline AFSIZE & $\begin{array}{l}0.528^{*} \\
(0.000)\end{array}$ & $\begin{array}{l}-0.052 \\
(0.493)\end{array}$ & $\begin{array}{l}0.389^{*} \\
(0.000)\end{array}$ & \\
\hline \multicolumn{5}{|c|}{$\begin{array}{l}\text { OIL \& GAS AND NAUTRAL } \\
\text { RESOURCES SAMPLE }\end{array}$} \\
\hline $\mathrm{AQ}$ & 1 & & & \\
\hline BIND & $\begin{array}{l}0.332^{*} \\
(0.000)\end{array}$ & 1 & & \\
\hline FOWNER & $\begin{array}{l}0.500^{*} \\
(0.000)\end{array}$ & $\begin{array}{l}-0.188^{*} \\
(0.024)\end{array}$ & 1 & \\
\hline AFSIZE & $\begin{array}{l}0.459^{*} \\
(0.000)\end{array}$ & $\begin{array}{l}-0.126 \\
(0.132)\end{array}$ & $\begin{array}{l}0.597^{*} \\
(0.000)\end{array}$ & 1 \\
\hline \multicolumn{5}{|c|}{$\begin{array}{l}\text { HEALTH, CONGLOMERATE } \\
\text { AND AGRICULTURE SAMPLE }\end{array}$} \\
\hline $\mathrm{AQ}$ & 1 & & & \\
\hline BIND & $\begin{array}{l}-0.023 \\
(0.759)\end{array}$ & 1 & & \\
\hline FOWNER & $\begin{array}{l}0.219^{*} \\
(0.003)\end{array}$ & $\begin{array}{l}0.293^{*} \\
(0.000)\end{array}$ & 1 & \\
\hline AFSIZE & $\begin{array}{l}0.518^{*} \\
(0.000)\end{array}$ & $\begin{array}{l}0.158^{*} \\
(0.035)\end{array}$ & $\begin{array}{l}0.214^{*} \\
(0.004)\end{array}$ & 1 \\
\hline
\end{tabular}

Source: Compilation of Researchers (2020).

Table 3 above shows the correlation result for the study. AQ was noticed to be positively correlated with BIND $(r=0.128$, FOWNER $(r=0.334)$ and AFSIZE $(r=0.500)$ for the full sample. For sector sample of the consumer goods, AQ was found to be positively related with FOWNER ( $\mathrm{r}=0.281$, AFSIZE $(r=0.528)$ while it was negatively correlated with BIND $(r=-0.091)$. All the variables exhibited relationship that is significant with AQ at 5\% significant level except BIND. For the sector sample of oil \& gas and other natural resources, AQ was correlated positively with FOWNER $(r=0.500)$ and AFSIZE $(r=0.459)$. All the other variables exhibit a relationship that is significant with AQ at $5 \%$ significance level. Finally, for the sample of the consumer goods sector, AQ was correlated positively with FOWNER $(r=0.219)$ and AFSIZE $(r=0.518)$ while it was correlated negatively with BIND $(r=$ 
-0.023). With the exception of BIND, all the other variables were found to exhibit a relationship that is significant with AQ at $5 \%$ significance level.

Table 4. Binary regression result for the full sample

\begin{tabular}{|c|c|c|c|c|c|c|}
\hline & $\begin{array}{r}\mathrm{M} \\
\text { (Bina }\end{array}$ & $\begin{array}{l}3 \\
\text { git) }\end{array}$ & $\begin{array}{r}\mathrm{M} \\
\text { (Bina }\end{array}$ & 14 & (Bin & $\begin{array}{l}15 \\
\text { ompit) }\end{array}$ \\
\hline & A & B & A & B & A & B \\
\hline C & $\begin{array}{c}-4.577^{*} \\
(-6.025) \\
\{0.000\}\end{array}$ & $\begin{array}{c}-7.562^{*} \\
(-6.703) \\
\{0.000\}\end{array}$ & $\begin{array}{l}-2.658^{*} \\
(-6.137) \\
\{0.000\}\end{array}$ & $\begin{array}{c}-4.646^{*} \\
(-6.100) \\
\{0.000\}\end{array}$ & $\begin{array}{c}-2.344^{*} \\
(-5.106) \\
\{0.000\}\end{array}$ & $\begin{array}{l}-5.266^{*} \\
(-7.161) \\
\{0.000\}\end{array}$ \\
\hline BIND & $\begin{array}{c}0.127 \\
(1.230) \\
\{0.219\}\end{array}$ & $\begin{array}{c}0.124 \\
(1.213) \\
\{0.225\}\end{array}$ & $\begin{array}{c}0.070 \\
(1.185) \\
\{0.236\}\end{array}$ & $\begin{array}{c}0.067 \\
(1.359) \\
\{0.174\}\end{array}$ & $\begin{array}{c}0.180 \\
(0.586) \\
\{0.558\}\end{array}$ & $\begin{array}{c}0.099 \\
(1.244) \\
\{0.213\}\end{array}$ \\
\hline FOWNER & $\begin{array}{l}0.030^{*} \\
(7.038) \\
\{0.000\}\end{array}$ & $\begin{array}{l}0.022^{*} \\
(4.706) \\
\{0.000\}\end{array}$ & $\begin{array}{l}0.017^{*} \\
(7.273) \\
\{0.000\}\end{array}$ & $\begin{array}{l}0.012^{*} \\
(4.773) \\
\{0.000\}\end{array}$ & $\begin{array}{l}0.020^{*} \\
(6.760) \\
\{0.000\}\end{array}$ & $\begin{array}{l}0.015^{*} \\
(4.454) \\
\{0.000\}\end{array}$ \\
\hline AFSIZE & & $\begin{array}{l}1.423^{*} \\
(5.567) \\
\{0.000\}\end{array}$ & & $\begin{array}{l}0.878^{*} \\
(5.854) \\
\{0.000\}\end{array}$ & & $\begin{array}{l}1.092^{*} \\
(6.182) \\
\{0.000\}\end{array}$ \\
\hline McFadden & 0.287 & 0.370 & 0.286 & 0.373 & 0.278 & 0.383 \\
\hline $\begin{array}{l}\text { R-Squared } \\
\text { LR Statistics }\end{array}$ & $\begin{array}{c}204.289^{*} \\
(0.000)\end{array}$ & $\begin{array}{c}259.035^{*} \\
(0.000)\end{array}$ & $\begin{array}{c}203.391^{*} \\
(0.000)\end{array}$ & $\begin{array}{c}260.817^{*} \\
(0.000)\end{array}$ & $\begin{array}{c}197.745^{*} \\
(0.000)\end{array}$ & $\begin{array}{c}267.448^{*} \\
(0.000)\end{array}$ \\
\hline $\log$ & -253.158 & -220.085 & -253.158 & -219.193 & -256.430 & -215.878 \\
\hline $\begin{array}{l}\text { Likelihood } \\
\text { (LL) }\end{array}$ & Logistic & Logistic & Normal & Normal & Gev & Gev \\
\hline $\begin{array}{l}\text { Probability } \\
\text { distribution }\end{array}$ & 513 & 505 & 513 & 505 & 513 & 505 \\
\hline $\mathrm{N}$ & 248 & 242 & 248 & 242 & 248 & 242 \\
\hline $\begin{array}{l}\text { Obs with } \\
\text { Dep }=0 \\
\text { Obs with } \\
\text { Dep }=1\end{array}$ & 265 & 263 & 265 & 263 & 265 & 263 \\
\hline
\end{tabular}

Note: (1) \{ \} are probability values; Parentheses ( ) are Z-statistic

(2) a: model that has no control variables; b: model that has control variables

(3) $* 5 \%$ respective significance level

Source: Compilation of Researchers (2020)

Table 4 above revealed the outcome of the logistic regression for the full sample. logit, probit as well as Gompit are noticed. To choose from the models, the Log Likelihood (LL) was then applied. The consent is that the higher the LL value, the better the outcome. Each of the binary model were specifically estimated: control variable was first excluded; and secondly, control variable (AFSIZE) was included. The result was noticed to be better in every model were control variable (AFSIZE) was included because the different independent variables equally give explanation of more changes in AQ which is the dependent variable. McFadden R-squared result for binary regressions with the inclusion of the control variables is: logit $=37 \%$; probits $=37.3 \%$; and gompit $=38.3 \%$. The LR statistic for the three models indicates that they are 5\% significant in explaining the dependent variable outcome. The Likelihood Huber/White Heteroskedasticity test indicates that the results of the binary regression are 
free from Heteroskedasticity problem that is usually associated with data (cross-sectional). For the performance of each of the explanatory variables, it is deduced that BIND exhibits a positive and insignificant impact at $5 \%$ (logit output, $\beta 2=0.124, p=0.225$; probit output; $\beta 2=0.067, p=0.174$; Gompit output; $\beta 2=0.099, \mathrm{p}=0.213$ ) and this is the likelihood that firms have audit quality. FOWNER exhibits a positive as well as significant impact at $5 \%$ (logit output, $\beta 6=0.022, \mathrm{p}=0.000$; probit output; $\beta 6=0.012, p=0.000$; Gompit output; $\beta 6=0.015, p=0.000)$ and this is the likelihood that firms have audit quality. Considering the control variable, AFSIZE exhibits a positive and significant impact $5 \%$ (logit output, $\beta 8=1.423, \mathrm{p}=0.000$; probit output; $\beta 8=0.878, \mathrm{p}=0.000$; Gompit output; $\beta 8=1.092$, $\mathrm{p}$ $=0.000)$ and this is the likelihood that firms have audit quality.

Table 5. Results of the binary regression for the samples of consumer goods

\begin{tabular}{|c|c|c|c|c|c|c|}
\hline & \multicolumn{2}{|c|}{$\begin{array}{c}\text { Model } 3 \\
\text { (Binary Logit) }\end{array}$} & \multicolumn{2}{|c|}{$\begin{array}{c}\text { Model } 4 \\
\text { (Binary Probit) }\end{array}$} & \multicolumn{2}{|c|}{$\begin{array}{c}\text { Model } 5 \\
\text { (Binary Gompit) }\end{array}$} \\
\hline & A & B & A & B & A & B \\
\hline $\mathrm{C}$ & $\begin{array}{l}-7.562^{*} \\
(-4.833) \\
\{0.000\}\end{array}$ & $\begin{array}{l}-9.703^{*} \\
(-4.095) \\
\{0.000\}\end{array}$ & $\begin{array}{l}-4.423^{*} \\
(-5.052) \\
\{0.000\}\end{array}$ & $\begin{array}{l}-5.784^{*} \\
(-4.315) \\
\{0.000\}\end{array}$ & $\begin{array}{l}-5.538^{*} \\
(-5.062) \\
\{0.000\}\end{array}$ & $\begin{array}{l}-7.455^{*} \\
(-4.456) \\
\{0.000\}\end{array}$ \\
\hline BIND & $\begin{array}{c}-0.416 \\
(-0.970) \\
\{0.332\}\end{array}$ & $\begin{array}{c}-0.644 \\
(-1.077) \\
\{0.282\}\end{array}$ & $\begin{array}{c}-0.265 \\
(-1.010) \\
\{0.312\}\end{array}$ & $\begin{array}{c}-0.412 \\
(-1.189) \\
\{0.234\}\end{array}$ & $\begin{array}{c}-0.316 \\
(-1.009) \\
\{0.313\}\end{array}$ & $\begin{array}{c}-0.420 \\
(-1.138) \\
\{0.255\}\end{array}$ \\
\hline FOWNER & $\begin{array}{l}0.032^{*} \\
(3.371) \\
\{0.001\}\end{array}$ & $\begin{array}{c}0.020 \\
(1.758) \\
\{0.079\}\end{array}$ & $\begin{array}{l}0.019^{*} \\
(3.458) \\
\{0.001\}\end{array}$ & $\begin{array}{c}0.012 \\
(1.835) \\
\{0.067\}\end{array}$ & $\begin{array}{l}0.023^{*} \\
(3.238) \\
\{0.001\}\end{array}$ & $\begin{array}{c}0.015 \\
(1.493) \\
\{0.135\}\end{array}$ \\
\hline AFSIZE & & $\begin{array}{l}1.195^{*} \\
(1.988) \\
\{0.046\}\end{array}$ & & $\begin{array}{l}0.745^{*} \\
(2.181) \\
\{0.029\}\end{array}$ & & $\begin{array}{l}1.034^{*} \\
(2.112) \\
\{0.035\}\end{array}$ \\
\hline $\begin{array}{ll}\text { McFadden } & \text { R- } \\
\text { Squared } & \\
\text { LR Statistics } & \end{array}$ & $\begin{array}{c}0.341 \\
76.099^{*} \\
(0.000)\end{array}$ & $\begin{array}{c}0.461 \\
96.792^{*} \\
(0.000)\end{array}$ & $\begin{array}{c}0.339 \\
75.753^{*} \\
(0.000)\end{array}$ & $\begin{array}{c}0.462 \\
97.004^{*} \\
(0.000)\end{array}$ & $\begin{array}{c}0.356 \\
79.556^{*} \\
(0.000)\end{array}$ & $\begin{array}{c}0.484 \\
101.552^{*} \\
(0.000)\end{array}$ \\
\hline $\begin{array}{l}\text { Log Likelihood } \\
\text { (LL) }\end{array}$ & $\begin{array}{l}-73.548 \\
\text { Logistic }\end{array}$ & $\begin{array}{l}-56.510 \\
\text { Logistic }\end{array}$ & $\begin{array}{l}-73.721 \\
\text { Normal }\end{array}$ & $\begin{array}{c}-56.403 \\
\text { Norvmal }\end{array}$ & $\begin{array}{c}-71.819 \\
\text { Gev }\end{array}$ & $\begin{array}{c}-54.130 \\
\text { Gev }\end{array}$ \\
\hline $\begin{array}{l}\text { Probability } \\
\text { distribution } \\
\mathrm{N}\end{array}$ & $\begin{array}{c}180 \\
56\end{array}$ & $\begin{array}{c}173 \\
51\end{array}$ & $\begin{array}{c}180 \\
56\end{array}$ & $\begin{array}{c}173 \\
51\end{array}$ & $\begin{array}{c}180 \\
56\end{array}$ & $\begin{array}{c}173 \\
51\end{array}$ \\
\hline $\begin{array}{l}\text { Obs with Dep = } \\
0 \\
\text { Obs with Dep }= \\
1\end{array}$ & 124 & 122 & 124 & 122 & 124 & 122 \\
\hline
\end{tabular}

Note: (1) \{ \} are probability values; Parentheses ( ) are Z-statistic

(2) a: model that has no control variables; b: model that has control variables

(3) $* 5 \%$ respective significance level

Source: Compilation of Researchers (2020).

The output of the binary regression for sector sample of the consumer goods is observed in table 5 above. The McFadden R-squared results of the 3 binary regression with firm size (control variables) included is: logit $=46.1 \%$; probits $=46.2 \%$; and gompit $=48.4 \%$. The LR statistic for the three models indicates that they are statistically significant at $5 \%$ to explain the result of the dependent variable. For the specific performance, it is observed that BIND exhibits inverse and insignificant impact at 5\% (logit 
output, $\beta 2=-0.644, \mathrm{p}=0.282$; probit output; $\beta 2=-0.412, \mathrm{p}=0.234$; Gompit output; $\beta 2=-0.420, \mathrm{p}=$ 0.255 ) on the likelihood that a company has audit quality. FOWNER exhibits a positive and insignificant impact $5 \%$ (logit output, $\beta 6=0.020, p=0.079$; probit output; $\beta 6=0.012, p=0.067$; Gompit output; $\beta 6$ $=0.015, \mathrm{p}=0.135)$ and this is the likelihood that firms have audit quality. Considering the control variable, AFSIZE exhibits a positive and significant impact at $5 \%$ (logit output, $\beta 8=1.195, \mathrm{p}=0.046$; probit output; $\beta 8=0.745, \mathrm{p}=0.029$; Gompit output; $\beta 8=1.034, \mathrm{p}=0.035)$ and this is the likelihood that firms have audit quality.

Table 6. Binary regression output for the samples of oil \& gas and natural resources

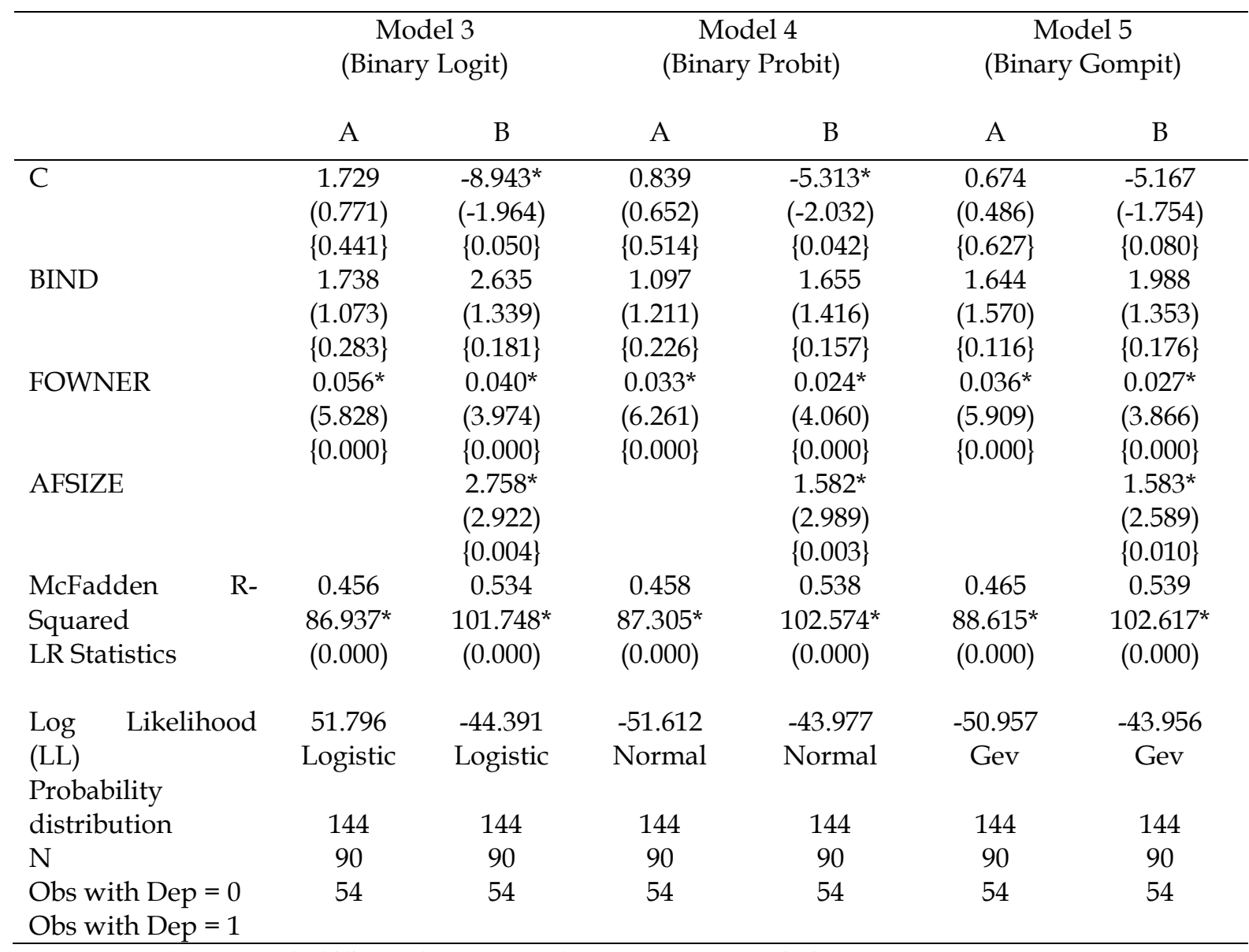

Note: (1) \{ \} are probability values; Parentheses ( ) are Z-statistic

(2) a: model that has no control variables; b: model that has control variables

(3) * 5\% respective significance level

Source: Compilation of Researchers (2020).

Table 6 indicates the regression of binary result for the sector sample of oil \& gas and natural resources. Result of the McFadden R-squared from the 3 binary regression with firm size (control variable) included is: logit $=53.4 \%$; probits $=53.8 \%$; and gompit $=53.9 \%$. The LR statistic for the 3 models indicates that they are statistically significant at $5 \%$ in explaining the result of the variable (dependent). The specific performance of the independent variables indicates that BIND exhibits a positive as well as insignificant impact at $5 \%$ (logit outcome, $\beta 2=2.635, \mathrm{p}=0.181$; probit outcome; $\beta 2$ $=1.655, \mathrm{p}=0.157$; Gompit outcome; $\beta 2=1.988, \mathrm{p}=0.176$ ) on the likelihood of a firm having audit quality. FOWNER exhibits a positive and significant impact at $5 \%$ (logit output, $\beta 6=0.040, p=0.000$; probit output; $\beta 6=0.024, p=0.000$; Gompit output; $\beta 6=0.027, p=0.000$ ) and this is the likelihood that firms have audit quality. Considering the control variable, AFSIZE exhibits a positive and 
significant at $5 \%$ impact (logit output, $\beta 8=2.758, \mathrm{p}=0.004$; probit output; $\beta 8=1.582, \mathrm{p}=0.003$; Gompit output; $\beta 8=1.583, \mathrm{p}=0.010$ ) and this is the likelihood that firms have audit quality.

Table 7. Binary regression output for the samples of health, conglomerate and agriculture

\begin{tabular}{|c|c|c|c|c|c|c|}
\hline & \multicolumn{2}{|c|}{$\begin{array}{c}\text { Model } 3 \\
\text { (Binary Logit) }\end{array}$} & \multicolumn{2}{|c|}{$\begin{array}{c}\text { Model } 4 \\
\text { (Binary Probit) }\end{array}$} & \multicolumn{2}{|c|}{$\begin{array}{c}\text { Model } 5 \\
\text { (Binary Gompit) }\end{array}$} \\
\hline & A & B & A & B & A & B \\
\hline C & $\begin{array}{c}-2.166 \\
(-1.030) \\
\{0.308\}\end{array}$ & $\begin{array}{l}-14.528 \\
(-3.584) \\
\{0.000\}\end{array}$ & $\begin{array}{l}-1.356 \\
(-1.084) \\
\{0.278\}\end{array}$ & $\begin{array}{l}-8.386^{*} \\
(-3.695) \\
\{0.000\}\end{array}$ & $\begin{array}{l}-1.469 \\
(-1.139) \\
\{0.255\}\end{array}$ & $\begin{array}{l}-10.284^{*} \\
(-3.967) \\
\{0.000\}\end{array}$ \\
\hline BIND & $\begin{array}{l}1.111 \\
(0.631) \\
\{0.528\}\end{array}$ & $\begin{array}{l}-1.358 \\
(-0.552) \\
\{0.581\}\end{array}$ & $\begin{array}{c}0.663 \\
(0.646) \\
\{0.518\}\end{array}$ & $\begin{array}{c}-0.963 \\
(-0.705) \\
\{0.481\}\end{array}$ & $\begin{array}{l}1.799 \\
(1.504) \\
\{0.133\}\end{array}$ & $\begin{array}{c}-0.322 \\
(-0.194) \\
\{0.846\}\end{array}$ \\
\hline FOWNER & $\begin{array}{l}0.029^{*} \\
(3.952) \\
\{0.000\}\end{array}$ & $\begin{array}{l}0.019^{*} \\
(2.070) \\
\{0.039\}\end{array}$ & $\begin{array}{l}0.017^{*} \\
(4.093) \\
\{0.000\}\end{array}$ & $\begin{array}{c}0.012 \\
(2.245) \\
\{0.025\}\end{array}$ & $\begin{array}{l}0.017^{*} \\
(3.648) \\
\{0.000\}\end{array}$ & $\begin{array}{l}0.013^{*} \\
(1.978) \\
\{0.048\}\end{array}$ \\
\hline AFSIZE & & $\begin{array}{l}3.906^{*} \\
(4.465) \\
\{0.000\}\end{array}$ & & $\begin{array}{l}2.257^{*} \\
(4.537) \\
\{0.000\}\end{array}$ & & $\begin{array}{l}2.843^{*} \\
(4.571) \\
\{0.000\}\end{array}$ \\
\hline $\begin{array}{l}\text { McFadden R- } \\
\text { Squared } \\
\text { LR Statistics }\end{array}$ & $\begin{array}{c}0.362 \\
90.358^{*} \\
(0.000)\end{array}$ & $\begin{array}{c}0.541 \\
134.203^{*} \\
(0.000)\end{array}$ & $\begin{array}{c}0.361 \\
90.010^{*} \\
(0.000)\end{array}$ & $\begin{array}{c}0.544 \\
134.799^{*} \\
(0.000)\end{array}$ & $\begin{array}{c}0.364 \\
90.730^{*} \\
(0.000)\end{array}$ & $\begin{array}{c}0.561 \\
139.041^{*} \\
(0.000)\end{array}$ \\
\hline $\begin{array}{l}\text { Log Likelihood } \\
\text { (LL) }\end{array}$ & $\begin{array}{l}-79.487 \\
\text { Logistic }\end{array}$ & $\begin{array}{l}-56.902 \\
\text { Logistic }\end{array}$ & $\begin{array}{c}-79.661 \\
\text { Normal }\end{array}$ & $\begin{array}{c}-56.604 \\
\text { Normal }\end{array}$ & $\begin{array}{c}-79.301 \\
\mathrm{Gev}\end{array}$ & $\begin{array}{c}-54.483 \\
\text { Gev }\end{array}$ \\
\hline $\begin{array}{l}\text { Probability } \\
\text { distribution }\end{array}$ & 180 & 179 & 180 & 179 & 180 & 179 \\
\hline $\mathrm{N}$ & 93 & 92 & 93 & 92 & 93 & 92 \\
\hline $\begin{array}{l}\text { Obs with Dep }= \\
0 \\
\text { Obs with Dep }= \\
1\end{array}$ & 87 & 87 & 87 & 87 & 87 & 87 \\
\hline
\end{tabular}

Note: (1) \{ \} are probability values; Parentheses ( ) are Z-statistic

(2) a: model that has no control variables; b: model that has control variables

(3) $* 5 \%$ respective significance level

Source: Compilation of Researchers (2020).

Table 7 revealed the regression of the binary result for the sector sample of health, conglomerate and agriculture. Outcome of McFadden R-squared from the 3 binary regression with firm size (control variables) included is: logit $=53.4 \%$; probits $=53.8 \%$; and gompit $=53.9 \%$. The LR statistic for the three models indicates that they are statistically significant at $5 \%$ to explain the result of the variable (dependent). The specific performance of the independent variables indicates that BIND exhibits inverse as well as insignificant impact at $5 \%$ (logit output, $\beta 2=-1.358, \mathrm{p}=0.581$; probit output; $\beta 2=-0.963$, $\mathrm{p}$ $=0.481$; Gompit output; $\beta 2=-0.322, \mathrm{p}=0.846$ ) and this is the likelihood that firms have audit quality. FOWNER exhibits a positive as well as significant impact at $5 \%$ (logit output, $\beta 6=0.019, p=0.039$; probit output; $\beta 6=0.012, p=0.025$; Gompit output; $\beta 6=0.013, p=0.048$ ) and this is the likelihood that firms have audit quality. Considering the control variable, AFSIZE exhibits a positive and significant impact at $5 \%$ (logit output, $\beta 8=3.906, p=0.000$; probit output; $\beta 8=2.257, p=0.000$; Gompit output; $\beta 8=2.843, \mathrm{p}=0.000$ ) and this is the likelihood that firms have audit quality. 


\section{Discussion}

Test of Hypotheses and Discussion of the Result

The full sample results form the basis for the hypotheses testing as well as the discussion of findings.

\subsection{Board Independence and Audit Quality}

Board independence exhibits a positive and insignificant impact at $5 \%$ (logit output, $\beta 2=0.124, \mathrm{p}=$ 0.225; probit output; $\beta 2=0.067, \mathrm{p}=0.174$; Gompit output; $\beta 2=0.099, \mathrm{p}=0.213$ ) on the likelihood that a company has audit quality. Hence, the null hypothesis (H01) is accepted that board independence does not have any significant influence with the audit quality of Nigeria quoted manufacturing companies. The finding is in line with some prior studies which found an insignificant association between board independence and that of audit quality (Gajevszky, 2014; Okaro et al., 2015). In addition, Bakare (2019) revealed that board independence has a significant effect on audit qaulity. Meanwhile the finding is against extant studies of Gajevszky (2014) and Okaro et al. (2015) who showed that board independence has an insignificant influence on audit quality. Also, Mohamed and Mohamed (2012) showed that there is a significant influence on audit quality. Similarly, Enofe, Mgbame, Aderin and EhiOshio, (2013) analysed and found a relationship that is positive and significant between board independence and that of audit quality. In the same vein, Stewart and mason (2006) found the percentage of independence directors to have a positive and significant impact on the quality of audit.

\subsection{Foreign Ownership and Audit Quality}

Foreign ownership appears to have a positive as well as a significant impact at $5 \%$ (logit output, $\beta 6=$ $0.022, \mathrm{p}=0.000$; probit output; $\beta 6=0.012, \mathrm{p}=0.000$; Gompit output; $\beta 6=0.015, \mathrm{p}=0.000$ ) on the likelihood that a company has audit quality. Hence, the null hypothesis (H02) is rejected that foreign ownership does not have any significant influence with the audit quality of Nigeria quoted manufacturing companies. The finding is in support of some prior studies which found a relationship that is significant between foreign ownership and the quality of audit (Uwuigbe et al., 2018). The motive for this positive relationship which exists between foreign ownership and the quality of audit is that foreign investors encourage companies to adopt better governance practices. Also, foreign investors perform an important role to ensure the demand of higher quality external audits, improving company's performance and enhancing company's corporate governance. Meanwhile the finding is against existing study of Akinwunmi, Adeyemi, Alao \& Ajayi-owoeye (2020) who showed that foreign ownership has a significant impact on the quality of audit.

\section{Conclusions}

The study investigated the implications of board independence and foreign ownership on audit quality of Nigeria quoted manufacturing companies. Based on a sample of fifty eight (58) quoted manufacturing companies in Nigeria over a period of nine (9) years (2010 - 2018), the study employed the binary model of regression (logit, probit as well as gombit) to test the hypotheses. The outcome of the study revealed that board independence has a positive and insignificant influence on the quality of audit of Nigeria quoted manufacturing companies. Also, foreign ownership has a positive and significant influence on the quality of audit of Nigeria quoted manufacturing companies. Conclusively, corporate governance (board independence and foreign ownership) respectively has an inverse and positive impact on the quality of audit of Nigeria quoted manufacturing companies. The study recommends that composition of the board should be such that its function is not undermined and one of such ways is to have an appropriate mixture with non-executive directors. Also having foreign ownership should be 
encouraged because it enhances audit quality of manufacturing companies. The study likewise has implication for research. It increases the existing literature on the implications of board independence and foreign ownership on the quality of audit of Nigeria quoted manufacturing companies. Though this study has contributed to knowledge in several ways, it has its own limitations; just two variables of corporate governance (board independence and foreign ownership) were used. It is therefore suggested that future studies should also work on other corporate governance variables to examine the implication on audit quality.

\section{References}

Akhalumeh, P., Agweda, F., \& Ogunkua, Z. (2017). Corporate characteristics and audit quality: Evidence from quoted firms in Nigeria. Journal of Scientific Research and Studies 4(3), 59-66.

Akinwunmi, A.J., Adeyemi, A.A., Alao, A.A., Ajayi-owoeye, O.A. (2020). Foreign ownership structure as a monitoring tool for audit quality: Evidence from Nigeria. European Journal of Business, Economics and Accountancy, 8(1), 1-61.

Bakare, I. (2019). Board independence and audit quality in Nigeria. Accounting and Taxation Review, $3(1), 1-11$.

Chen, Y., Hsu, J., Huang, M., \& Yang, P. (2013). Quality, size, and performance of audit firms. The International Journal of Business and Finance Research, 7(5), 1-17.

DeAngelo, L.E. (1981). Auditor size and audit quality. Journal of Accounting and Economics, 3, 183199.

Dwekat, A., Mardawi, Z., \& Abdeljawad, I. (2018). Corporate governance and auditor quality choice. Evidence from Palestinian corporation. International Journal of Economics and Financial issues, $8(2), 47-53$.

Enofe, A.O., Mgbame, C., Aderin, A., \& Ehi-Oshio, O.U. (2013). Determinants of audit quality in the Nigerian business environment. Research journal of finance and Accounting, 4(4), 36-43.

Enofe, A.O., Mgbame, C., Efayena, O., \& Edegware, J. (2014). Audit firm characteristics on auditing quality; The Nigerian Experience. Research Journal of finance and Accounting, 5(6), 23-34.

Gajevszky, A. (2014). Aduit quality and corporate governance. Evidence from more Buchares Stock Exchange. Journal of Economics and Social Development, 1(2), 1-11.

Gillan, S.L., \& Starks, L.T. (2003). Corporate governance proposal and shareholder activism. The role of institutional investors. Journal of Financial Economics, 57(2), 1-32.

Ilaboya, O.J., \& Iyafekhe, C. (2014). Corporate governance and audit report lag in Nigeria. International Journal of Humanities and Social science, 4(13), 1-9.

Kakler, H.M., Kangarlouei, S.J., \& Motavassel, M. (2012). Audit quality and financial reporting quality: Case of Tehran Stock Exchange (TSE). Innovative journal of Business and Management, 1(3), 43 47.

Kee, H.W., Hock, O.Y., \& Kueng, K.C. (2017). Corporate governance quality and audit quality in Malaysia. SHS web of conferences 34, accessed on 18 July, 2019.

Ling, Chiek \& Seong, (2016). Foreign ownership, foreign directors and the profitability of Malaysian listed companies. Procedia - Social and Behavioral Sciences 219, 580-588. 
Nengzih, M. (2017). determinant of corporate governance, audit quality and financing decisions. Research Journal of Finance and Accounting, 8(8), 113-120.

Mohammed, M.S., \& Mohammed, A.E. (2012). Corporate governance practices and audit quality. An empirical study of the listed companies in Egypt. International Journal of Social, Behavioral, Educational, Economic, Business and Engineering, 6(11), 3101-3106.

Okaro, S.C., Okafor, G.O., \& Okoye, E.I. (2015). Corporate governance and audit quality. The Institute of Charctered Accountant of Nigeria First Academic Conference of Accounting and Finance. 102121.

Oxelheim \& Randov (2003). The impact of foreign board membership on firm value. Journal of Banking \& Finance 27(12), 2369-2392.

Peel, M.J., \& Makepeace, G.H. (2012). Differential audit quality, propensity score matching and rosentiaum bounds for confounding variables. Journal of Business Finance and Accounting, 39(56), 606-648.

Rittenberg, L.E., Johnstone, K.M., \& Gramling, A.A. (2010). Auditing: A business risk approach (8th ed). US: Cengage Learning. 1056.

Stewart, S. Z. J., \& Manson, S. (2006). The impact of board composition and ethnicity on audit quality: Evidence from Malaysian companies. Malaysian Accounting Review, 5, 61-83.

Tambun, S., Sitorus, R.R., Panjaitan, I., \& Hardiash, A.Z. (2017). The effect of good corporate governance and audit quality on the earnings, quality moderated by firm size. International Journal of Business, Economics and Law, 14(5), 48-56.

Uwuigbe, U., Eluyela, D.F., Uwuigbe, O.R., Obarakpo, T., \& Falola. I. (2018). corporate governance and quality of financial statements. A study of listed Nigerian banks. Banks and Banks System, 13(3), 12-23.

Wakil, G.K., Alifiah, M.N., \& Teru, P. (2020). Auditor independence and audit quality in Nigeria public sector: A critical review. Journal of critical reviews, 1-7.

Implikasi Independensi Dewan dan Kepemilikan Asing pada Kualitas Audit perusahaan Manufaktur di Nigeria

\begin{abstract}
Abstrak
Penelitian ini menganalisis implikasi dari independensi dewan dan kepemilikan asing pada kualitas audit perusahaan manufaktur Nigeria. Tujuan khusus dari penelitian ini adalah untuk menguji pengaruh independensi dewan serta kepemilikan asing terhadap kualitas audit perusahaan manufaktur. Studi ini menggunakan data sekunder untuk mengumpulkan total lima puluh delapan (58) perusahaan manufaktur yang dikutip Nigeria untuk periode 2010 hingga 2018. Model regresi biner (logit, probit dan juga gombit) digunakan dengan tepat untuk menguji hipotesis. Hasil penelitian menunjukkan bahwa independensi dewan berpengaruh positif dan tidak signifikan terhadap kualitas audit sedangkan kepemilikan asing berpengaruh positif dan signifikan terhadap kualitas audit. Studi tersebut kemudian merekomendasikan bahwa komposisi dewan harus sedemikian rupa sehingga fungsinya tidak rusak dan salah satu cara tersebut adalah memiliki campuran yang sesuai dengan direktur non-eksekutif. Memiliki kepemilikan asing dapat meningkatkan kualitas audit mengingat budaya perusahaan yang berbeda yang mungkin mereka miliki.
\end{abstract}

Kata kunci: kualitas audit, independensi dewan, kepemilikan asing, perusahaan manufaktur, Nigeria 